\title{
IAMJ
}

INTERNATIONAL

AYURVEDIC

MEDICAL JOURNAL

\section{IMPORTANCE AND PROCEDURE FOR ANALYSIS OF MEDA DHATU}

\author{
Kavita Kaushik $^{1}$, Ruby Rani Aggarwal ${ }^{2}$ \\ ${ }^{1}$ PG Scholar, Dept. of Rog Nidana Evum Vikriti Vigyan, Rishikul Campus, UAU, Haridwar, Uttarakhand, India \\ ${ }^{2}$ Professor \& Head of the Dept, Dept. of Rog Nidana Evum Vikriti Vigyan, Rishikul Campus, UAU, Haridwar, \\ Uttarakhand, India
}

Corresponding Author: vaidyakavitakaushik@gmail.com

https://doi.org/10.46607/iamj2209122021

(Published Online: December 2021)

Open Access

(C) International Ayurvedic Medical Journal, India

Article Received: 18/11//2021 - Peer Reviewed: 26/11/2021 - Accepted for Publication 02/12/2021

\section{Check for updates}

\begin{abstract}
Ayurveda, the most ancient science means knowledge of life which serves mankind by providing a comprehensive, natural and holistic cure for diseases related to mind and body. The aim of Ayurveda is not only to treat the disease but also to protect the health of the healthy individual as said in the classics i.e., "swasthasya swasthya rakshanam aturasya vikara prashmanam ch". Health in Ayurveda is defined as an accurate amount of Dosha, Dhatu and Mala. Any type of variations in quantity as well as quality leads to diseases. One of the dhatus i.e., Meda Dhatu is correlated with fat and lipid in modern science. This paper is about the method by which Meda Dhatu can be assessed according to Ayurveda.
\end{abstract}

Keywords: meda, dhatu, swasthasya, assessment

\section{INTRODUCTION}

Ayurveda, the most ancient medical science is the knowledge of life gifted by sages of ancient times. The aim of Ayurveda is not only to treat the disease but also to protect the health of a healthy individual
"Swasthasya swasthya rakshanam aturasya vikar prashmanam ch" ${ }^{1}$. The Ayu (life span) in Ayurveda is defined as a combination of Sharir, Indriya, Satva and Atma ${ }^{2}$. In Ayurveda classic definition of Swastha 
refers to the accurate quantity of Dosha, Dhatu and $M_{a l a^{3}}$ and any variations in their quantity or quality leads to diseases. The body consists of seven dhatus, one of them is Meda Dhatu. These seven Dhatus are sequentially formed, and this process takes 6 days according to Acharya Charka ${ }^{4}$. According to Acharya Sushruta and Acharya Vagbhatta, it takes 1 month (18090 Kala $)^{5}$. According to Acharya Sushruta formation of the first Dhatu i.e., Rasa Dhatu from the Ahara Rasa (digestive product of food) consumes one day but after that, every Dhatu formation consumes 5 days each. So, the formation of Meda takes 15 days. As per the description in Ayurvedic literature, Meda Dhatu is originated from Mamsa Dhatu.

\section{Location of Meda:}

In human body, Meda resides in Medodhara Kala ${ }^{6}$. In the modern era, Kala can be identified as a membrane. Despite few places like testicles, eyelids etc Medodhara Kala is present almost all over the body beneath the Mamsadhara Kala. Meda is deposited especially in Vapavahan ${ }^{7}$ (related with the omentum of the belly), over the pelvic region, around the blood vessels to protect it from the shock and around eyeballs.

\section{Aetiology of Medo Vridhi:}

Meda is increased due to lack of exercise, sleeping during the day and intake of diet increasing Kapha which leads to the increment of $M e d a^{8}$. This excess of Meda and Kapha leads to blockage of Srotas (channels in the body) and finally Medo Vridhi .

\section{Aetiology of Meda Kshaya:}

Meda Dhatu Kshaya can be correlated with Atikrishta, which is mentioned among the Asthanindita Purusha ${ }^{10}$ in Charka Samhita Sutra Sthana. This Atikrishta leads to various diseases such as Pliha Vriddhi, Kasa, Kshaya, Swasa, Gulma Arsha, Udara, Grahani and Udar Roga ${ }^{11}$. Meda Dhatu decreases due to malnourishment of Rasa Dhatu by fasting, excessive exercise, excessive work, insomnia, excessive bathing, the persistence of disease for a long time (Chronic disease) and Vatavardhaka Ahara Vihara $^{12}$.

\section{Assessment of Meda Dhatu:}

In Charaka Samhita, Acharya Charka has mentioned Anjali pramana for the measurement of all physical elements of the body in Sharirsankhyasharir Adhyaya. The Pramana of Meda Dhatu is 2 Anjali $^{13}$, but it is difficult and almost impossible to assess. So, its increase (Vriddhi), vitiation (Dushti), decrease (Kshaya) and optimum condition (Sara) of Meda Dhatu can be assessed by its features mentioned in Ayurvedic classics. The features are as follows:

Features of Meda Sara ${ }^{14}$ and assessment method:

Meda Sara means qualitative as well as quantitative assessment of Meda Dhatu

\begin{tabular}{|l|l|l|l|}
\hline S. No. & Meda Sara & Assessment via \\
\hline 1. & स्रेहयुक्त स्वर & delicate voice & Observation \\
\hline 2. & स्नेहयुक्त नेत्र & unctuousness in eyes & Question and inspection \\
\hline 3. & स्नेहयुक्त केश & oily hairs or lustrous hairs & Question and inspection \\
\hline 4. & स्नेहयुक्त रोम & lustrous body hairs & Question and inspection \\
\hline 5. & स्रेहयुक्त नख & shiny nails & Inspection \\
\hline 6. & स्नेहयुक्तदन्त & shiny teeth & Inspection \\
\hline 7. & स्नेहयुक्तऔष्ठ & lustrous lips & Question and inspection \\
\hline 8. & स्नेहयुक्तमूत्र & $\begin{array}{l}\text { oily urine or Chyluria i.e., the presence lym- } \\
\text { phatic fluid that contains fat and protein, } \\
\text { leaks into with body }\end{array}$ & $\begin{array}{l}\text { Evaluating a postprandial sample of urine } \\
\text { for chlomicrons and triglycerides }\end{array}$ \\
\hline 9. & स्नेहयुक्तपुरीष & $\begin{array}{l}\text { fatty faeces or steatorrhea i.e., presence of } \\
\text { fat in faeces due to lack of absorbing fat or } \\
\text { nutrients }\end{array}$ & $\begin{array}{l}\text { Quantitative assessment of faecal fat by } \\
\text { CFA (coefficient of fat absorption) }\end{array}$ \\
\hline 10. & बृहतशरीर & large body assessed by Angul Praman men- & Angul Pramana (in Ayurveda classics) \\
\hline
\end{tabular}




\begin{tabular}{|l|l|l|l|}
\hline 11. & $\begin{array}{l}\text { आयाम/ परिश्रम } \\
\text { सहिष्णु }\end{array}$ & Qun in Ayurveda classics & Question and exercise tolerance test \\
\hline 13. & $\begin{array}{l}\text { वितैश्वर्य } \\
\text { सुखोपभोग } \\
\text { प्रदनान्यार्जवं }\end{array}$ & $\begin{array}{l}\text { individual possesses wealth, power, happi- } \\
\text { ness, enjoyment etc }\end{array}$ & Question \\
\hline 14. & सुकुमरोपचारता & delicate appearance & visual inspection \\
\hline
\end{tabular}

The above points are mentioned to assess Meda Dhatu Sara (optimum condition of Meda Dhatu). This Sara of Meda can be assessed as follow:
If the features mentioned above are present then an individual may be considered as MedaSsara Purusha otherwise it may be considered as Meda Kshaya, Vridhi or Dusti.

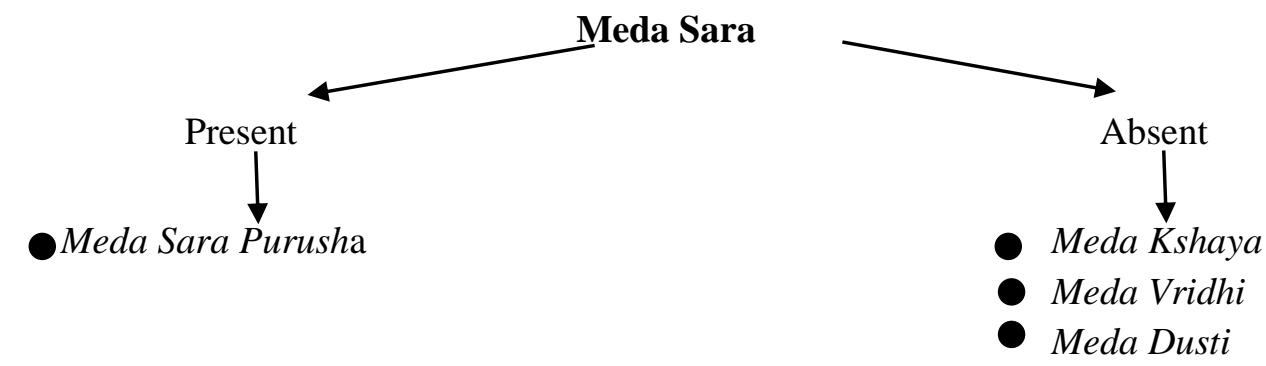

Features of meda Kshaya ${ }^{15}$ and assessment method:

Meda Kshaya means the quantitative decrease in Meda Dhatu.

\begin{tabular}{|l|l|l|l|}
\hline S.No. & \multicolumn{2}{|c|}{ Meda Kshaya } & Assessment via \\
\hline 1. & संधीनां स्फुटनं & joint crepitation & $\begin{array}{l}\text { Inspection } \\
\text { Question }\end{array}$ \\
\hline 2. & ग्लानि & Irritation & Question \\
\hline 3. & अक्ष्णोआयास & lassitude of eyes & Hip waist ratio \\
\hline 4. & तनुत्वं चोदरस्य & decrease waist circumference & Inspection by touch \\
\hline 5. & स्वपनं कटयाः & numbness in the pelvic region & $\begin{array}{l}\text { Features of other Dhatu and investigation } \\
\text { for tuberculosis }\end{array}$ \\
\hline 6. & शोष & depletion of other Dhatus or tuberculosis & Skin-fold thickness (sum of all four sites) \\
\hline 7. & कृशाअड्ग्ता & muscle wasting & Palpation and percussion \\
\hline 8. & प्लीहाभिवृद्धि & Splenomegaly & Question and inspection \\
\hline 9. & संधि शून्यता & numbness in joint and lack of strength in joints & Touch \\
\hline 10. & रौक्ष्य & Dryness & Question \\
\hline 11. & मेदुरमांसप्रार्थनां & desire of fatty food & BMI (Body mass index) \\
\hline 12. & काशर्य & lean and thin & Question \\
\hline 13. & श्रम & weakness after mild exertion & \\
\hline
\end{tabular}

The above points are mentioned to assess Meda Dhatu Kshaya (decrease in the quantity of Meda
Dhatu). This Kshaya of Meda can be assessed as follows: 
- If the features present are $<50 \%$ then it may be considered as Avar Meda Kshaya (mild decrease in Meda Dhatu)

- If the features present are 50\%-75\% then it may be considered as Madhyam Meda Kshaya (moderate decrease in Meda Dhatu)

\section{Features of Meda Vridhi ${ }^{16}$ :}

- If the features present are $>75 \%$ then it may be considered as Pravar Meda Kshaya (sever decrease in Meda Dhatu)

\begin{tabular}{|l|l|l|l|}
\hline S.No. & \multicolumn{2}{|c|}{ Meda vridhi } & Assessment via \\
\hline 1 & अल्पsपि चेष्टा श्वासनम् & dysponea on mild exertion & Asking questions and observation \\
\hline 2 & स्फ़िक् उदर लम्बनम् & increase the circumference of the butt, \& abdomen & Waist hip ratio \\
\hline 3 & स्निर्ध अड्ग्ता & unctuousness of body & Observation (via touch) \\
\hline 4 & कास & cough & Question/Auscultation \\
\hline 5 & श्वास & Breathlessness & Observation/Question \\
\hline 6 & दौर्गन्धः & foul smell & Question and Observation \\
\hline
\end{tabular}

Meda Vridhi means quantitative increment of Meda Dhatu.

The above points are mentioned to assess Meda Dhatu Vridhi (increment in the quantity of Meda Dhatu). The Vridhi of Meda can be assessed as follows:

- If the features present are $<50 \%$ then it may be considered as Avar Meda Vridhi (mild increment in Meda Dhatu)

Features of Meda Dusti ${ }^{17}$ :

Meda Dusti means qualitative changes of Meda Dhatu.

\begin{tabular}{|c|c|c|c|}
\hline S.No. & \multicolumn{2}{|c|}{ Meda Dusti } & Assessment via \\
\hline 1 & जवोपरोधः & lack of enthusiasm & Question (history taking) \\
\hline 2 & कृष्छ्रव्यवायता & lack of sexual activity & Question (history taking) \\
\hline 3 & दौर्बल्य & Weakness & Question (history taking) \\
\hline 4 & दौर्गंध & foul smell & Question \& Observation (by smell) \\
\hline 5 & स्वेदाबाध & uncomfortable due to sweating & Question \& Observation \\
\hline 6 & क्षुद अतिमात्रा & Polyphagia & Question \\
\hline 7 & पिपासातिमात्रा & Polydipsia & Question \\
\hline 8 & जटिलीभावकेशे & complex hair & Question \& observation (appearance) \\
\hline 9 & माधुर्य आस्य & the sweet taste of mouth & Question \\
\hline 10 & करपाद सुप्त दाह & $\begin{array}{l}\text { numbness and burning sensation in hand and } \\
\text { feet }\end{array}$ & Question \& inspection (via touch) \\
\hline 11 & मुख तालु कण्ठशोष & dryness of mouth & Question \\
\hline 12 & आलस्य & feeling of laziness & Question \\
\hline 13 & मलिन काय छिद्र उपदेहः & ugly appearance due to excess secretions of & Inspection / question \\
\hline
\end{tabular}

- If the features present are 50\%-75\% then it may be considered as Madhyam Meda Vridhi (moderate increment in Meda Dhatu)

- If the features present are $>75 \%$ then it may be considered as Pravar Meda Vridhi (sever increment in Meda Dhatu) 


\begin{tabular}{|l|l|l|l|}
\hline 14 & अड्गुपरिदाह और सूप्तता & $\begin{array}{l}\text { mucous from orifices of the body } \\
\text { the feeling of burning sensation and numb- } \\
\text { ness of body parts }\end{array}$ & Question / inspection (via touch) \\
\hline 15 & $\begin{array}{l}\text { षटपदपिपीलिकाभिश्च } \\
\text { शरीर आभिसरणम् }\end{array}$ & $\begin{array}{l}\text { roaming or attracting of fly, ants, butterflies } \\
\text { etc toward the patient body }\end{array}$ & Question \\
\hline 16 & $\begin{array}{l}\text { मूत्रे च मूत्रदोषान } \\
\text { change in the normal physical appearance of } \\
\text { urine }\end{array}$ & $\begin{array}{l}\text { Routine and microscopic examination } \\
\text { of urine }\end{array}$ \\
\hline 17 & $\begin{array}{l}\text { विस्त्र शरीरगन्ध } \\
\text { foul smell }\end{array}$ & Question \\
\hline 18 & निद्रा & excessive sleep & Question \\
\hline 19 & तन्द्रा & Drowsiness & \\
\hline
\end{tabular}

Above points that mentioned to assess Meda dhatu dusti (vitiation of Meda Dhatu). The Meda Dusti can be assessed as follows:

* If the features present are $<50 \%$ then it may be considered as Avar Meda Dusti (mild vitiation in Meda Dhatu)

* If the features present are 50\%-75\% then it may be considered as Madhyam Meda Dusti (moderate vitiation in Meda Dhatu)

* If the features present are $>75 \%$ then it may be considered as Pravar Meda Dusti (sever vitiation in Meda Dhatu)

\section{DISCUSSION}

On the basis of the above procedure for analysis of Medo Dhatu we can assess Medo Dusti, Vridhi and Kshya. In brief, we can say that these disorders are related to the involvement of Dhathavagni and Bhutagni. The abnormality of Dhatvagni especially Meda Agni is responsible for these Medo Vikaras. As we know that Medo Dushti leads to Sthaulya, Prameha etc Medo Vridhi leads to Granthi, Galganda, Arbudh etc. These derangements of Meda Dhatu are due to deranged metabolism such as Obesity, Diabetes, Hypothyroidism etc. If we assess the status of Medo Dhatu, we can prevent various metabolic disorders in a very early stage.

\section{CONCLUSION}

Meda dhatu vitiation (dushti), increase (vridhi) and decrease (kshya) lead to various diseases, which are mentioned under Meda pradosha vikara described in Sushruta Samhita Sutra Sthana. Meda pradosha vikaras are granthi, vridhi, galganda, gandmala, arbudha, medoj austha, atisthaulya etc. The procedure for analysis of meda dhatu can be formatted as per the different features described in the classic texts of Ayurveda and it is very important to assess the status of Meda dhatu for the following reasons:

- To diagnose and cure the disease.

- To maintain the status of Meda in an equilibrium state for a healthy lifestyle.

- To manage the Prakritika karma of Meda dhatu such as snehan (lubrication) of body, production of sweda (sweat), dridhatava (the solidity of the body), asthipushti (nourishment of bone).

\section{REFERENCES}

1. Shastri Kashinath, Chaturvedi Gorakhnath, editor. Vidyotni Commentary on Charaka Samhita of Acharya Charaka, Sutrasthana; Arthedashmahamooliya Adhyaya: Chapter 30, Verse26. Varanasi: Chaukhambha Bharti Academy reprint 2018; p. 587.

2. Shastri Kashinath, Chaturvedi Gorakhnath, editor. Vidyotni Commentary on Charaka Samhita of Acharya Charaka, sutra sthana; Deerghajiviteeya Adhyaya: Chapter 1, Verse 42. Varanasi: Chaukhambha Bharti Academy reprint 2018; p. 13.

3. Shastri A, editor. Hindi commentary Ayurved tatva sandipika on Sushruta Samhita of Acharya Sushruta, sutra sthana; Dosa dhatumala vigyaniya Adhyaya: Chapter 15, Verse 48. Varanasi: Chaukhambha Sanskrit Sansthan series, 2006; p. 84.

4. Shastri Kashinath, Chaturvedi Gorakhnath, editor. Vidhotyni commentary on Charaka Samhita of Acharya Charaka, Chikitsa sthana; Grahnichikitsa Adhyaya: Chapter 15 Verse 21. Varanasi; Chaukhambha Bharti Academy reprint 2018; p. 382 
5. Shastri A, editor. Hindi commentary Ayurved tatva sandipika on Sushruta Samhita of Acharya Sushruta, sutra sthana; Sonita varnaniya Adhyaya: Chapter 14, Verse 15. Varanasi: Chaukhambha Sanskrit Sansthan series, 2006; p. 66.

6. Shastri A, editor. Hindi commentary Ayurved tatva sandipika on Sushruta Samhita of Acharya Sushruta, sharir sthana; .......... Chapter 4, Verse 12. Varanasi: Chaukhambha Sanskrit Sansthan series, 2006; p. 39.

7. Shastri Kashinath, Chaturvedi Gorakhnath, editor. Vidyotni Commentary on Charaka Samhita of Acharya Charaka, Viman sthana; Srotovimanroganika Viman: Chapter 5, Verse 7. Varanasi: Chaukhambha Bharti Acadmeyreprint 2018; p. 711

8. Shastri Kashinath, Chaturvedi Gorakhnath, editor. Vidyotni Commentary on Charaka Samhita of Acharya Charaka, Viman sthana; Srotovimanroganika Viman: Chapter 5, Verse 16. Varanasi: Chaukhambha Bharti Acadmeyreprint 2018; p. 713.

9. Shastri Kashinath, Chaturvedi Gorakhnath, editor. Vidyotni Commentary on Charaka Samhita of Acharya Charaka, sutra sthana; Asthauniditiya Adhyaya: Chapter 21, Verse 9. Varanasi: Chaukhambha Bharti Acadmeyreprint 2018; p. 411.

10. Shastri Kashinath, Chaturvedi Gorakhnath, editor. Vidyotni Commentary on Charaka Samhita of Acharya Charaka, sutra sthana; Asthauniditiya Adhyaya: Chapter 21, Verse 3. Varanasi: Chaukhambha Bharti Acadmeyreprint 2018; p. 407.

11. Shastri Kashinath, Chaturvedi Gorakhnath, editor. Vidyotni Commentary on Charaka Samhita of Acharya Charaka, sutra sthana; Asthauniditiya Adhyaya: Chapter 21, Verse 14. Varanasi: Chaukhambha Bharti Acadmeyreprint 2018; p. 412.

12. Shastri Kashinath, Chaturvedi Gorakhnath, editor. Vidyotni Commentary on Charaka Samhita of Acharya Charaka, sutra sthana; Asthauniditiya Adhyaya: Chapter 21, Verse 12. Varanasi: Chaukhambha Bharti Academy reprint 2018; p. 411.

13. Shastri Kashinath, Chaturvedi Gorakhnath, editor. Vidyotni Commentary on Charaka Samhita of Acharya Charaka, sharira sthana; Sharirsankhya Sharira Adhyaya: Chapter 7, Verse 15. Varanasi: Chaukhambha Bharti Acadmeyreprint 2018; p. 915.

14. Shastri Kashinath, Chaturvedi Gorakhnath, editor. Vidyotni Commentary on Charaka Samhita of Acharya Charaka, viman sthana; Rogabhishakagjitiyaviman Adhaya: Chapter 8, Verse 106.
Varanasi: Chaukhambha Bharti Academy reprint 2018; p. 776.Shastri A, editor. Hindi commentary Ayurved tatva sandipika on Sushruta Samhita of Acharya Sushruta, Sutra sthana; Aturopakarmaniya Adhyaya: Chapter 35, Verse 18. Varanasi: Chaukhambha Sanskrit Sansthan series, 2006; p. 170.

15. Shastri Kashinath, Chaturvedi Gorakhnath, editor. Vidyotni Commentary on Charaka Samhita of Acharya Charaka, Sutra sthana; Kiyantashirasihya Adhaya: Chapter 17, Verse 66. Varanasi: Chaukhambha Bharti Academy reprint 2018; p. 348. Shastri A, editor. Hindi commentary Ayurved tatva sandipika on Sushruta Samhita of Acharya Sushruta, sutra sthana; Dosha dhatumalavigyaniya Adhyaya: Chapter 15, Verse 13. Varanasi: Chaukhambha Sanskrit Sansthan series, 2006; p. 76.

Tripathi B, editor Nirmala Hindi commentary on Astanga hridyam of Acharya vaggbhatta, Sutra sthana; doshaadivigyaniya Adhyaya; Chapter 11, Verse18. Delhi: Chaukhamba Sanskrit Pratishthan reprint 2017; p. 164.

16. Shastri A, editor. Hindi commentary Ayurved tatva sandipika on Sushruta Samhita of Acharya Sushruta, sutra sthana; Dosha dhatumalavigyaniya Adhyaya: Chapter 15, Verse 19. Varanasi: Chaukhambha Sanskrit Sansthan series, 2006; p. 76.

Tripathi B, editor Nirmala Hindi commentary on Astanga hridyam of Acharya vaggbhatta, Sutra sthana; doshaadivigyaniya Adhyaya; Chapter 11, Verse10. Delhi: Chaukhamba Sanskrit Pratishthan reprint 2017; p. 162.

17. Shastri Kashinath, Chaturvedi Gorakhnath, editor. Vidyotni Commentary on Charaka Samhita of Acharya Charaka, Sutra sthana; Prameha Nidana: Chapter 4, Verse 47. Varanasi: Chaukhambha Bharti Academy reprint 2018; p. 640.

\section{Source of Support: Nil Conflict of Interest: None Declared}

How to cite this URL: Kavita Kaushik \& Ruby Rani Aggarwal: Importance And Procedure For Analysis Of Meda Dhatu. International Ayurvedic Medical Journal \{online\} 2021 \{cited December 2021\} Available from: http://www.iamj.in/posts/images/upload/3063 3068.pdf 